\title{
Retraction Note: The Effect of Digital Storytelling Method in Science Education on Academic Achievement, Attitudes, and Motivations of Secondary School Students
}

Kadir Bilen, Mustafa Hoştut, Mustafa Büyükcengiz

\begin{tabular}{|c|c|}
\hline ISSUE DATE & ORIGINAL ARTICLE \\
\hline 15 Sep. 2020 & $\begin{array}{l}\text { Bilen, K., Hoştut, M., \& Büyükcengiz, M. (2019). The Effect of Digital Storytelling Method in Science Education on } \\
\text { Academic Achievement, Attitudes, and Motivations of Secondary School Students. Pedagogical Research, 4(3), } \\
\text { em0034. https://doi.org/10.29333/pr/5835 }\end{array}$ \\
\hline
\end{tabular}

Original Article is retracted at the request of the corresponding author. All authors agree to this retraction. 